\title{
Interactions between Monetary Policy and Exchange Rate in Inflation Targeting Emerging Countries: The Case of Three East Asian Countries
}

\author{
Siok Kun Sek \\ Economics Department, Christian Albrechts University of Kiel \\ Olshausenstr. 66A-007, 24118 Kiel, Germany \\ Tel: 49-431-888-6969Ｅ-mail: siokksek@bwl.uni-kiel.de
}

\begin{abstract}
This paper investigates empirically how the reaction of monetary policy to exchange rate has changed after the adoption of inflation targeting regime in three East-Asian countries. Using a system equation of structural VAR and a single equation approaches, this paper shows that the reactions of monetary policy to exchange rate shocks as well as CPI (demand shocks) and output (supply shocks) have declined under the inflation targeting environment. The policy function reacts weakly to the exchange rate movements before and after the financial crisis of 1997 in two out of the three countries. These central banks react differently to inflation. Empirical estimations of policy reaction functions indicate that the policy maker in Philippines pays higher concerns on output gap stability in the post-crisis period although Philippines has implemented the inflation targeting regime.
\end{abstract}

Keywords: Exchange rate, Inflation targeting, Policy reaction function

\section{Introduction}

Although the role of exchange rate in the setup of monetary policy in emerging market is no longer new in the international macroeconomics literatures, it still remains as a hot topic for debates among researchers. The research on the design of monetary policy rule before was based on the case of closed economy. For example, in the simple Taylor rule, interest rate as the policy instrument is a weighted function of inflation and output gap. This rule does not give a direct role to the exchange rate.

However, in the real world, economies are quite open and the exchange rate movements can be matter in the design of monetary policy. Many studies suggest the inclusion of exchange rate term in the policy reaction function and show that exchange rate plays an improving role in the performances of monetary policy rules and enhances higher welfare of agents (for examples Ball (1999), Batini et.al (2001) and Senay (2001)). Exchange rate contributes to the demand channel through the effects of relative price (foreign and domestic goods) and creates the direct exchange rate channel through the convert of domestic currency prices of foreign produced goods. It affects the aggregate demand for domestic goods (Senay, 2001).

On the other hand, there are opinions which against this view. There are arguments that central banks should concern the effects of exchange rate fluctuations on inflation and output gap rather than giving an independence role for the exchange rate in the policy reaction (Mishkin (2000) and Schmidt-Hebbel (2002)). The reasons are exchange rate already has the indirect effects on inflation and output in the policy reaction function. Giving a direct role to exchange rate in the Taylor rule may add volatility to the monetary policy (Taylor, 2001).

This paper extends the studies on the role of exchange rate in the monetary policy reaction under the inflation targeting environment in three inflation targeting East-Asian countries. It seeks to investigate the relationship between monetary policy and exchange rate from two perspectives: the impulse response of monetary policy to exchange rate shocks and the responses of monetary policy to exchange rate movements. Two approaches are applied in this study, i.e the system equation approach of structural VAR and the single equation of GMM. First, using the system equation of structural VAR approach, this study seeks to investigate how the monetary policy responds to the exchange rate disturbances/ shocks before and after the adoption of inflation targeting regime. How large the effect of exchange rate shocks is accounted for in the forecast error variances decomposition for monetary policy as compare to the other shocks? Second, using the single equation of GMM, this study seeks to estimate the coefficients of the policy reaction function with respect to the policy targets such as output gap and inflation as compare to that of exchange rate between the two sub-periods. Through this estimation, one can observe how does the policy react to the exchange rate shocks and movements and how does the reaction change between the two sub-periods.

The main findings of this study are the responses of monetary policy to shocks including the exchange rate shocks have declined in the post-crisis period. At the same time, the price or inflation shocks can explain higher forecast errors of monetary policy relative to other shocks. The policy makers in these countries react differently to exchange rate 
movements and inflation variable. With the exception of Thailand, the policy reaction functions in Korea and Philippines do not react significantly to the exchange rate movements in the two sub-periods. The results imply that central banks in these countries do not follow as what they have claimed. Although these countries have implemented the inflation targeting after the financial crisis, only Thailand shows a significance reaction of monetary policy to the inflation variable. The policy maker in Philippines pays higher concerns on output gap stability after the crisis.

The remainder of the paper proceeds as follows. Section two reviews the literature on the relationship between monetary policy and the exchange rate. Section three is about the data. Section four discusses the methodologies. Section five discusses the results. Section six concludes.

\section{The issue of exchange rate in emerging countries - some reviews}

There are numerous empirical studies that investigate the relationship between monetary policy and exchange rate. In general, the main literatures that address the relationship between the exchange rate and the monetary policy can be divided into three categories. The first category examines the change in the degree of exchange rate pass-through after the adoption of inflation targeting or compares the pass-through rate in inflation targeting and non inflation targeting countries. The second category investigates and compares the results of the volatility of exchange rate in inflation targeting and non inflation targeting countries. The third category examines the responses of the monetary policy to the exchange rate movements before and after the adoption of inflation targeting regime.

The research in the exchange rate pass-through shows that exchange rate and monetary policy are correlated to each other. Many studies show that exchange rate pass-through in emerging countries is higher than that in the developed countries. Therefore, it is argued that emerging countries face higher difficulties in their efforts to target at low inflation rate and maintain price stability (Minella et.al, 2003, Fraga, 2003 and Nogueira Junior, 2007). However, a number of studies show that the pass-through rate has declined in many countries and researchers have different explanations for that. One of the famous explanations is that low pass-through rate correlates with low inflation rate as a consequence of strong commitment towards price stability by Taylor (2000). The view of Taylor is supported by many empirical studies such as Edwards (2006), Gagnon and Ihrig (2004) and Nogueira Junior (2007).

The inter-relationship between exchange rate and monetary policy can also be captured through the volatility in exchange rate. Emerging countries tend to pay greater concerns on achieving the exchange rate stability than that of developed countries do as they have lower credibility to control the low inflation rate. It is argued that the inflation targeting countries should float the exchange rate for the proper implementation of this regime due to the theory of 'Impossibility of the Holy Trinity' where the capital mobility and the monetary policy independence cannot be achieved under the pegged or fixed exchange rate regime (Mishkin \& Savastano (2001)). As mentioned in Mishkin (2004), controlling the exchange rate movements may generate two risks, i.e the risk of transforming the exchange rate into a nominal anchor that takes over the inflation target and the risk where the movements of exchange rate may depend on the nature of shocks. Therefore arguably, the inflation targeting countries may experience higher exchange rate volatility. However, some empirical studies show that this hypothesis does not hold (for example, Edwards (2006)).

The role of exchange rate in the design of monetary policy rules is another way to study the relationship of exchange rate and monetary policy. The results from the empirical studies are quite controversial. By estimating the Taylor rule type policy rules, Mohanty \& Klau (2004) show that in most of the emerging countries, the monetary policy responds to exchange rate strongly. Frömmel \& Schobert (2006) estimate simple Taylor type policy rules for six Central and Eastern European countries. They find that exchange rate plays an important role in the monetary policy during the fixed exchange rate regimes periods. However, the influence disappears after these countries have moved to the flexible regimes. On the other hand, Osawa (2006) in his study on three Asian inflation targeting countries finds no evidence of monetary policy responds to the exchange rate. He argues that the reason for this difference result is because the existing studies do not consider structural breaks of data in their estimations. Besides, including the crisis period in the sample of estimation may overestimate the response of monetary policy to exchange rate. This paper conducts the analysis within this category.

\subsection{Exchange rate regimes and monetary policy in Asian}

The financial crisis of 1997 and 1998 in East-Asian countries has totally changed the monetary policies and exchange rate regimes in these countries. According to the International Monetary Financial (IMF) classifications, Korea has moved from managed floating to independently floating regime after the crisis. Thailand on the other hand, has moved from pegged exchange rate to managed floating regime while Philippines remains the same regime as independently floating after the crisis (see Table 1). The move from rigidity to more flexible regimes give some effects on the volatility of exchange rate, foreign exchange reserves and the interest rate (see Table 2). In general, the change in the regimes leads to higher fluctuations in exchange rate in three East-Asian countries considered in this study. However, the foreign exchange reserves and interest rate have declined in all three countries after the crisis. 
Besides moving to the more flexible exchange rate regimes, these Asian countries also alter their monetary policy and adopt the inflation targeting regime after the financial crisis of 1997. Korea was the first country in East-Asian that has adopted the inflation targeting regime, i.e in April 1998. Thailand followed the step in May 2000 and later Philippines in January 2002 (Osawa, 2006). For more detail on the monetary policy framework in these countries, see Table 1.

Officially, these countries are moving to more flexible exchange rate regimes and these central banks claim that they do not consider a direct role for the exchange rate in their policy reaction functions in the post-crisis period. Do the central banks in these countries follow as what they have claimed? How large the effect of exchange rate in the policy reaction function and how does the role of exchange rate change in the pre- and post-crisis periods (or after the switch of policy regimes) in these countries? These are all the main focus of this paper.

\section{Data}

This study focuses on the three crisis-hit East-Asian countries that have moved from the rigid exchange rate regime to the flexible one and inflation targeting regime after the crisis namely Korea, Philippines and Thailand. These countries have adopted the inflation targeting regime at different time. i.e Korea in April 1998, Thailand in May 2000 and Philippines in January 2002. For the purpose of this study, the data is divided into two sub-periods referring to the starting year of the adoption of inflation targeting regime. The full sample series are from 1990M1 to 2007M5. Period I indicates the pre-crisis period or the period before the adoption of inflation targeting. It spans from the beginning of 1990 to 1997M6 (Note 1). Period II represents the post-crisis period and the starting period of the adoption of inflation targeting regime. The range is different across countries. Korea takes the range of 2000M1 to 2007M5, Philippines 2002M1 to 2007M5 and Thailand 2000M5 to 2007M5 (Note 2).

This study uses two sets of data. The first set of data is used to estimate the system equation of SVAR models while the second set of data is used to estimate the GMM single equation model. The data are in monthly and are obtained from the International Financial Statistics (IFS), IMF. The first set of data consists of money demand or M1 (M), bilateral nominal national local currency per USD exchange rate (EX), consumer price index (CPI), industrial/ manufacturing production index (IP), the oil price of the world (OIL), money market rate or short-term interest rate (I) and Federal Fund rate (FFR). All the series are in logarithm form except the interest rate. The construction of the data and the representation of the variables are explained in Table 3(a). All the data are tested with the unit-root tests and are transformed into the stationary form before conducting the estimations (see Table 4).

The second set of the data consist of short term interest rate (I), output gap (GAP), annually inflation rate (PI) and the growth rate of exchange rate (see Table 3(b)). The output gap is defined as the deviation of log industrial production index from its HP filtered trend series. The annual rate of inflation is constructed as the log current CPI deviates from the log 12th lagged of CPI. The change in exchange rate is constructed as the log differenced of exchange rate series from its one lagged term.

The single equation approach of GMM is applied using the second data set and periods as defined above. However, due to the data availability problem and the structure of the system equation, the estimation of the SVAR model may take a slightly different time paths defined above (refer Table 5).

\section{Methodology}

This study applies two different approaches namely the structural VAR and the single equation based on Generalized Method of Moments (GMM). Using a structural VAR approach, this paper seeks to investigate the effects of exchange rate shocks to monetary policy. In the second part, a single equation based on GMM is used to estimate the responses of policy reaction function to exchange rate movements.

\subsection{SVAR}

This study takes the ideas and modifies the structural VAR model in Kim (2003) and Kim \& Roubini (2000) that identifies the exogenous policy shocks and policy reaction functions. Following Kim (2003) and Kim \& Roubini (2000), the economy can be described as:

$$
G(L) y_{t}=e_{t}
$$

$\mathrm{G}(\mathrm{L})$ represents a matrix in the lag operator $\mathrm{L}, y_{t}$ is the (n $\left.\mathrm{x} 1\right)$ vector and $e_{t}$ is an (n $\left.\mathrm{x} 1\right)$ disturbance vector with variance $\operatorname{var}\left(e_{t}\right)=\Lambda$ and $\Lambda$ is a diagonal matrix. The general reduced form of VAR equation takes the form of:

$$
y_{t}=B(L) y_{t-1}+u_{t}
$$

where $\mathrm{B}(\mathrm{L})$ is a matrix of lag operator and $\operatorname{var}\left(u_{t}\right)=\Sigma$.

As discussed in Kim (2003), there are different ways to recover the parameters in the structural form equation from the reduced form equation. One of the methods is the so-called generalized method. This method assigns restrictions on the contemporaneous structural parameters and allows non-recursive structures.

$$
B(L)=-G_{0}^{-1} G^{0}(L)
$$


where $G^{0}(L)$ is the coefficient matrix without the contemporaneous coefficient $G^{0}$. Given that $\Sigma=G_{0}^{-1} \Lambda G_{0}^{-1}$ and $\sum$ contains $\mathrm{n}(\mathrm{n}+1) / 2$ parameters, we need at least $\mathrm{n}(\mathrm{n}-1) / 2$ restrictions on $G^{0}$ (for further detailed explanations, see $\operatorname{Kim}(2003))$.

In this study, seven variables are included in the VAR model. These variables are interest rate (I), monetary aggregate or M1 (M), consumer price index (CPI), output (IP), world price of oil in terms of the US Dollar (OIL), Federal funds Rate of the US (FFR) and the exchange rate as units of US Dollar (EX). Therefore, the vector of stationary endogenous variables can be written as:

$$
y_{t}=\left[\begin{array}{lllllll}
I_{t} & M_{t} & C P I_{t} & I P_{t} & O I L_{t} & F F R_{t} & E X_{t}
\end{array}\right]^{\prime}
$$

The first four variables are the variables used in the standard international macroeconomics model or monetary business cycle model. Following Kim \& Roubini (2000), FFR and OIL have the function of isolating 'exogenous' monetary changes. As discussed in Kim \& Roubini (2000), the recession and price inflation in the economy can be due to the monetary contraction and original supply shocks. Therefore, in order to identify the shocks due to the monetary policy alone, the oil price index is used as a proxy for inflationary supply shocks. FFR is used to control for the component of domestic monetary policy that react to the foreign monetary policy shocks. Finally, nominal exchange rate is used as to investigate the reaction of monetary policy to the exchange rate shocks in the small open economies.

All the series are in log form (except the interest rate series) in order to capture the percentage change in the variables. Applying the unit-root test of Augmented Dicky Fuller (ADF) and Schmidt Phillips (SP) to the two sub-periods sample shows that in most cases, these variables are not stationary in their levels. As discussed in Ramaswamy and Sloek (1997), there are three ways to specify the non-stationary series in a VAR system, i.e either to specify the series in differenced form, specify them in levels or consider the cointegration relationships among the variables under consideration by applying a vector error correction model (VECM). VECM is considered when the cointegration relationship is known. However, if the relationship is unknown, VECM can be biased and it could be more appropriate to consider the VAR in levels. This paper applies a structural VAR model in differenced form in order to generate efficient estimators (Note 3). The length of lag is determined by referring to the optimum lag suggested by Akaike Info Criterion, Final Prediction Error and Schwarz Criterion and by checking the fulfillment of diagnostic tests. A constant term and seasonal dummies are included in the model (Note 4).

As in Kim \& Roubini (2000), the restrictions on the contemporaneous structural parameters can be written as follows (Note 5):

$$
\left[\begin{array}{c}
e_{t}^{I} \\
e_{t}^{M} \\
e_{t}^{C P I} \\
e_{t}^{I P} \\
e_{t}^{O L L} \\
e_{t}^{I F R} \\
e_{t}^{E X}
\end{array}\right]=\left[\begin{array}{ccccccc}
1 & 0 & G_{13} & G_{14} & G_{15} & 0 & G_{17} \\
G_{21} & 1 & G_{23} & G_{24} & 0 & 0 & 0 \\
0 & 0 & 1 & G_{34} & G_{35} & 0 & 0 \\
0 & 0 & 0 & 1 & G_{45} & 0 & 0 \\
0 & 0 & 0 & 0 & 1 & 0 & 0 \\
0 & 0 & 0 & 0 & G_{65} & 1 & 0 \\
G_{71} & G_{72} & G_{73} & G_{74} & G_{75} & G_{76} & 1
\end{array}\right]\left[\begin{array}{c}
u_{t}^{I I} \\
u_{t}^{M} \\
u_{t}^{C P I} \\
u_{t}^{I P} \\
u_{t}^{O L} \\
u_{t}^{F F R} \\
u_{t}^{E X}
\end{array}\right]
$$

where $G$ represents the values of non-restrictions; zero restrictions are assigned on the contemporaneous structural parameters. The structural disturbances (left hand side) represent the shocks of interest rate, money aggregate, consumer price index, output, oil price, foreign monetary policy and exchange rate respectively. The ' $u$ ' terms in the right hand side are the residuals in the reduced form which can be interpreted as unexpected movements of variables in the system equation.

Apart from the original restriction used by Kim \& Roubini (2000) that apply to the G-7 countries, this paper modifies the restriction on the monetary policy reaction function. In this paper, the monetary policy reaction function is assumed to follow a Taylor rule type equation i.e the interest rate reacts to CPI (price level), IP (output) and EX (exchange rate). As in Kim \& Roubini (2000), the exchange rate and the oil price variables are included in the monetary reaction function in order to control the current responses of monetary policy to the state of the economy.

Apart from this, the second reason to include the exchange rate terms in the policy reaction function is to capture the reaction of interest rate (monetary policy) to this variable over time in the small open economies environment. In order to investigate how significance the role of exchange rate in the monetary policy, I first allow the interest rate policy reacts to the exchange rate (model I) and later restrict the reaction to zero (model II), i.e $\mathrm{B}(1,7)=0$.

The other six equations follow the restrictions or identifications as in Kim \& Roubini (2000). The second equation is the money demand function that depends on the real income (CPI and IP) and the opportunity cost of holding money (nominal interest rate). The third equation is the CPI inflation equation that assumed to respond to the output and inflationary pressure of the world's oil price. The output is a function of inflationary pressure of oil price variable. 
Following Kim \& Roubini (2000), the oil price is assumed to affect prices and the real sector contemporaneously. The foreign monetary policy reacts to the oil inflationary pressure shocks. The exchange rate equation represents the financial market equilibrium and receives the contemporaneous effects of all variables in this model.

As explained in Kim \& Roubini (2000), the first two equations represent the money market equilibrium, the third and forth equations describe the domestic goods market equilibrium, the fifth and sixth equations as exogenous shocks from the foreign countries and the last equation describes the exchange rate market.

\subsection{Generalized Method of Moments - Monetary policy reaction function}

In the second approach, this study applies Generalized Method of Moments technique in estimating the monetary policy reaction function. Following Mohanty and Klau (2004) and Osawa (2006), the monetary policy reaction function takes the form of:

$$
\begin{gathered}
i_{t}=\alpha_{0}+\alpha_{1} \pi_{t}+\alpha_{2} G A P_{t}+\alpha_{3} \Delta E_{t}+\alpha_{4} \Delta E_{t-1}+\alpha_{5} i_{t-1} \\
i_{t}=\alpha_{0}+\alpha_{1} \pi_{t}+\alpha_{2} G A P_{t}+\alpha_{5} i_{t-1}
\end{gathered}
$$

where $\mathrm{i}$ is the interest rate policy reaction function; $\pi$ is the inflation rate target and GAP is the output gap target; $\mathrm{E}$ is the $\log$ exchange rate target and $\Delta$ denotes the first differenced operator. The lag term of interest rate acts as the smoothing term. As discussed in Osawa (2006), $\alpha_{1}>1$ indicates that the central bank attempts to stabilize the inflation. If $\alpha_{1}<1$, the increase in nominal interest rate is lower than the real interest rate to fully offset the increase in the inflation shocks. According to Mohanty and Klau (2004), $\alpha_{3}>0$ and $\alpha_{4}><0 . \alpha_{4}$ can be positive or negative because the exchange rate is assumed to be mean reverting (Note 6). Equation (4) is the policy reaction function which reacts to exchange rate movements but equation (5) does not. Both policy reaction functions are estimated separately using the data of the two sub-periods for the three inflation targeting Asian countries (Note 7).

\section{Results}

\subsection{Results - SVAR}

The results of SVAR are based on the contemporaneous coefficients in the SVAR models, the impulse response functions and the forecast error variance decompositions. The results give us the effects of disturbances or economic shocks on the variables in the system and the reactions of variables to shocks.

Estimating the SVAR models that include and exclude the exchange rate term do not give very different results except the case of period I (pre-crisis period) in Korea and period II (post-crisis period) in Thailand. In the case of Korea in period I, excluding the exchange rate term in the SVAR model gives more reasonable results of impulse response functions. Conversely, in the case of period II in Thailand, excluding the exchange rate term in the model does not give the right reaction of CPI in response to the monetary policy shocks as predicted by theories. The results suggest that the policy reaction function in Korea before the crisis may not react significantly to exchange rate term. On the other hand, the policy reaction in Thailand after the crisis may react to exchange rate term. For the other cases where no very different results with and without exchange rate term in the model, the results suggest that the exchange rate term does not have significance effects on the policy reaction functions or the policy reaction functions may not react significantly or strongly to the exchange rate term.

The following discussions are based on the results of the coefficients of SVAR, impulse response function and forecast error variance decomposition. As discussed above, the results of including and excluding the exchange rate term in the model do not change very much, this paper only displays the results that include the exchange rate term (model I) with the exception of Korea in period I.

The results of SVAR are checked with diagnostic tests, i.e the tests for autocorrelation, conditional heteroskedasticity and non-normality (see Table 5). In most cases, the tests are not able to reject the hypothesis of no autocorrelation, no heteroskedasticity and non-normality at $5 \%$ significance level. The presence of non-normality may due to the unavoidable very short series of data used in the analysis.

Table 6 summarizes the results of estimated coefficients. Consistent to the results reported in Kim \& Roubini (2000), the estimated values of G13, G14, G15 and G17 are negative in most cases, implying a contractionary policy in response to the inflationary pressures. The coefficient for G13 is larger relative to the other coefficients, implying that the central banks in these countries are concerned about the inflation or price stability. On the other hand, the estimated coefficient of G17 is relatively smaller (with the exception of Thailand), implying that the reaction of policy reaction function to exchange rate is relatively small. In Thailand, the policy reaction function is strongly impacted by the exchange rate shocks. In all cases, the likelihood ratio test show that the identifying restrictions are not significant at the significance level.

The results of the impulse response function (IRF) for model I are summarized in Table 9(a-c). The middle line represents the responses while the upper and lower dashed lines are two standard error bands. In general, the reactions 
of the domestic variables to a one percent monetary policy shocks are consistent as predicted by the economic theories. The monetary policy interest rate shocks lead to the increase in interest rate, but the decline in M1, CPI and appreciation in exchange rate.

Apart from the effects of monetary policy shocks, the reactions of monetary policy interest rate to domestic shocks are also observed and summarized in Table 9(c). The increase in CPI (demand shock) and output growth (supply shock) as well as the depreciation in exchange rate (exchange rate shock) lead to the increase in interest rate. In the case of period II in Korea, the increase in interest rate is followed by its decline afterwards. In Thailand, the increase in output growth does not followed by the tightened in interest rate.

Table 7 reports the results of numerical values of impulse response functions of monetary policy interest rate to the inflation, output growth and exchange rate shocks. In general, the magnitudes of the change in the policy reaction in response to the domestic shocks (CPI, output and exchange rate) have declined after the financial crisis of 1997. These results do not necessary mean that the policy reaction functions in these countries do not react to these three shocks but it could be due to the decline on the effects of the shocks or lower persistency of shocks in period II (after the recovering from the crisis).

Although the effects of these three shocks have declined over time, the results of the forecast error variance decomposition (FEVD) show that the maximum explanatory power of CPI or inflation shocks on the forecast error variance of the policy reaction function in these three East-Asian countries has increased after the adoption of inflation targeting (see Table 8). This implies greater concerns of the authorities on price stability. On the other hand, the maximum determination power of exchange rate on policy reaction function remains low in Korea and Philippines but increases sharply in Thailand from at most $3 \%$ to at most $43 \%$ or at a mode of $24 \%$ in period II. Thailand adopted the fixed exchange rate regime before the financial crisis of 1997-98 but has switched to the floating regime and inflation targeting after the financial crisis. The switch from the fixed regime to the flexible one means exchange rate is allowed to fluctuate freely which generates higher volatility in the exchange rate or greater exchange rate shocks.

\subsection{Results - GMM}

Using the Generalized Method of Moments approach, equation (4) and (5) are estimated for the two sub-periods. The instruments variables consist of one to four lags of output gap, inflation, interest rate and nominal exchange rate (Note 8). Therefore, the number of overidentifying restrictions for equation (4) and equation (5) are 12 and 14 respectively. The chi-square of overidenfying restrictions at $5 \%$ significance level are 21.0 and 23.7 respectively. In all cases, the sizes of sample (adjusted for the degree of freedom) multiply with $J$ values are smaller than the values of chi-square, i.e the overidentifying restrictions cannot reject at the 5\% significance level. The results are summarized in Table 11 and 12 below. The results of GMM give us the ideas on how the policy reaction functions react to the economic variables over time. As in the SVAR approach, excluding the exchange rate term in the policy reaction function does not change much the results. On the other hand, the policy reaction functions in all the three countries react significantly to the interest rate smoothing term.

Table 11 summarizes the results of policy reaction coefficients. It is observed that Thailand is the only country where the monetary policy reacts to exchange rate (EX) in the pre- and post-crisis periods. Thailand is also the only country that follows the Taylor Principle, i.e the long-run coefficient for the policy responds to inflation exceeds unity or $\left(\alpha_{1} / 1-\alpha_{5}\right)>1$. The central bank in Thailand raises the real interest rate higher than the nominal interest rate in response to the increase in inflation rate. The policy reaction functions in the other two countries namely Korea and Philippines do not react significantly to the exchange rate (EX) term.

Comparing the results before and after the crisis, it is observed that the policy reaction equation of (4) and (5) fit the data very well in the post-crisis period or after the implementation of inflation targeting regime where the short-term interest rate is used as the policy instrument. Before the implementation of inflation targeting regime, the equations fit badly the data in Philippines. The results also show that the policy makers react differently to inflation. The policy makers in Korea and Thailand are concerned about the inflation or price stability. Philippines although has implemented the inflation targeting regime, the policy reaction function in Philippines does not react significantly to the inflation variable but reacts strongly to the output gap in period II. In Korea, the policy reaction function reacts significantly to inflation in both sub-periods. However, the coefficient of inflation in the policy reaction function is very small and closed to zero in period II. The same results also reported in Osawa (2006). According to Osawa (2006), the low response of BOK (Bank of Korea) to inflation does not necessarily imply the failure of inflation targeting regime in Korea but it can be interpreted as the achievement of low inflation in Korea induced by inflation targeting regime. Hence there is low response of monetary policy to inflation in Korea in period II. This condition can be observed from the line graph.

Table 10 shows the line graphs of short-term interest rate and annually inflation rate for these three countries. As observed in Korea, the inflation rate is lower and more stable in period II. The interest rate in period II is constant in 
responds to lower inflation environment. In Thailand, there is a co-movement of inflation and interest rate and inflation rate gains stability after the implementation of inflation targeting regime. In Philippines, the interest rate does not react accordingly to control the fluctuations in inflation rate. There is no significance improvement in the inflation rate.

Table 12 shows the estimated results of policy reaction functions that exclude the exchange rate terms. Excluding the exchange rate terms in the policy reaction function does not affect the policy reactions to other variables in the equation in all cases. Excluding the exchange rate term (EX) in the policy reaction function even generates higher R-square and lower standard error in Korea and Philippines. On the other hand, since the monetary policy in Thailand reacts to exchange rate term (EX) strongly in period I, excluding the exchange rate term in the policy reaction function gives lower R-square and higher standard error in period I. However, excluding the exchange rate term in period II in Thailand generates better fit of data. In general, the results of GMM are consistent to the results of SVAR, i.e the policy reaction functions in Korea and Philippines do not react significantly to exchange rate directly in both sub-periods and there is a strong response of policy reaction function in Thailand to exchange rate movements in the pre-crisis period.

\section{Conclusion}

Economists and researchers have different opinions on the role of exchange rate in the design of monetary policy in emerging market. The move of exchange rate regime from rigid to flexible and inflation targeting induces more debates on the relationship between monetary policy and exchange rate. Researchers have different explanations on the decline of the degree of exchange rate pass-through and the lower relationship between the monetary policy and exchange rate variables under the inflation targeting environment. While some researchers explain this as the contribution of the positive effects of inflation targeting, others refer this as the result of foreign exchange intervention. They argue that the lower correlation between monetary policy and exchange rate variables does not mean that there is no role for exchange rate in the design of policy rule but this may due to the intervention activity.

Applying a structural VAR and GMM approaches, this paper seeks to find out the answer on the relationship between the monetary policy and exchange rate in three East-Asian countries that have moved to the inflation targeting regime after the financial crisis of 1997-98. In particular, this paper seeks to compare the result before and after the change to more flexible exchange rate regimes and the adoption of inflation targeting regime. Applying a SVAR approach to investigate the response of policy reaction function to exchange rate shocks, the results of impulse response functions show that the responses of interest rate to domestic variables shocks (as well as exchange rate shock) have declined. Although the price level is less volatile and more stable (as well as other variables), the relative explanatory power of CPI shocks on monetary policy has increased after the adoption of inflation targeting regime. The explanatory power of exchange rate shocks on the other hand, remains low in two out of three countries in this study.

Consistent to the results reported in SVAR models, the results of GMM show that the policy reaction function in two East-Asian countries react weakly to the exchange rate movements. In both approaches, excluding the exchange rate term in the policy reaction function does not generate large changes in the policy reaction function with the exception of Thailand in period II. This is because the policy function does not show a significance response to the exchange rate movements directly. However, this does not mean that the exchange rate does not play a role in the monetary policy in these countries. The exchange rate may influence the movements of policy reaction function indirectly through its effects on the domestic variables such as inflation and output gap. On the other hand, the central bank may react to the exchange rate movements through intervention in the foreign exchange market as argued in many studies (for example Osawa (2006), Disyatat \& Galati (2005)).

The estimated results also imply that the central banks in these countries do not follow what they have claimed. For example, Philippines although has implemented the inflation targeting regime, the policy reaction function in Philippines does not react significantly to the inflation variable but reacts strongly to the output gap in period II. There is an evidence of the policy reaction responds directly to the exchange rate terms in the post-crisis period.

\section{References}

Adolfson, M. (2001). Incomplete exchange rate pass-through and single monetary policy rules. Working paper series in Economics \& Finance no. 478. [Online] Available: http://swopec.hhs.se/hastef/papers/hastef0478.pdf.

Ball, L. (1998). Policy rules for open economies. National Bureau of Economic Research. NBER working paper series 6760. [Online] Available: http://www.nber.org/papers/w6760.pdf

Ball, L. (1999). Policy rules for open economies. In Taylor,J.(Eds.), Monetary policy rules. University of Chicago Press, Chicago.

Ball, L. (2000). Policy rules and external shocks. National Bureau of Economic Research. NBER working paper series 7910. [Online] Available: http://www.nber.org/papers/w7910.pdf.

Batini, N, Harrision, R \& Millard, S. P. (2001). Monetary policy rules for an open economy. Bank of England. [Online] Available: http://papers.ssrn.com/sol3/papers.cfm?abstract_id=296823 
Billmeier, A. (2002). Current account fluctuations: how important are nominal shocks? European University Institute. [Online] Available: http://www.socialpolitik.de/tagungshps/2003/papers/Billmeier.pdf.

Breitung, J, Brüggemann, R \& Lütkepohl, H. (2004). Structural vector autoregressive modeling and impulse responses. In Lütkepohl,H \& Kratzig, N.(Eds.), Applied time series econometrics. Cambridge University Press.

Brischetto, A \& Voss, G. (1999). A structural vector autregression model of monetary policy in Australia. Bank of Australia Research Discussion paper 1999-11. [Online] Available: http://www.rba.gov.au/rdp/rdp1999-11.pdf.

Campa, J. M \& Goldberg, L. S. (2002). Exchange rate pass-through into import prices: a macro or micro phenomenon?. National Bureau of Economic Research. NBER working paper no. 8934.

Campa, J. M \& Goldberg, L. S. (2002). Exchange rate pass-through into import prices: a macro or micro phenomenon? National Bureau of Economic Research. NBER working paper. [Online] Available: http://www.nber.org/papers/w8934.pdf.

Côté, D Kuszczak, J, Lam, J. P, Liu,Y \& St-Amant, P. (2002). The performance and robustness of simple monetary policy rules in models of the Canadian economy. Bank of Canada. Technical report no. 92. [Online] Available: http://www.bankofcanada.ca/en/res/tr/2002/tr92.pdf.

Disyatat, P \& Galati, G. (2005). The effectiveness of foreign exchange intervention in emerging market countries. Bank of International Settlements. BIS papers no. 24. [Online] Available: http://www.bis.org/publ/bppdf/bispap24.pdf.

Edwards, S. (2006). The relationship between exchange rates and inflation targeting revisited. National Bureau of Economic Research. NBER working paper series no. 12163. . [Online] Available: http://www.nber.org/papers/w12163.pdf

Fraga, A, Goldfajn, I \& Minella, A. (2003). Inflation targeting in emerging market economies. National Bureau of Economic Research. NBER Working paper 10019. [Online] Available: http://www.nber.org/papers/w10019 Frömmel, M \& Schobert,F. (2006). Monetary policy rules in Central and Eastern Europe. Universität Hannover and Deutsche Bundesbank. Discussion paper no. 341. [Online] Available: http://www.wiwi.uni-hannover.de/Forschung/Diskussionspapiere/dp-341.pdf

Gagnon, J. E. \& Ihrig, J. (2004). Monetary policy and exchange rate pass-through. Board of Governors of Federal Reserve System. [Online] Available: http://www.federalreserve.gov/pubs/ifdp/2001/704/ifdp704r.pdf.

Gerlach, S \& Smets, F. (2000). MCIs and monetary policy. European Economic Review, 44, 1677-1700.

Kim,S \& Roubini, N. (2000). Exchange rate anomalies in the industrial countries: a solution with a structural VAR approach. Journal of Monetary Economics, 45, 561-586.

Kim,S. (2003). Monetary policy, foreign exchange intervention, and the exchange rate in a unifying framework. Journal of International Economics, 60, 355-386.

Lewis,K.K. (1995). Are foreign exchange intervention and monetary policy related, and does it really matter? The Journal of Business, 68, 185-214.

Minella, A et. al. (2003). Inflation targeting in Brazil. Constructing credibility under exchange rate volatility. Journal of International Money and Finance, 22, 1015-1040.

Mishkin, F. S. (2000). Inflation targeting in emerging market countries. National Bureau of Economic Research. NBER working paper series no. 7618. [Online] Available: http://www.nber.org/papers/w7618.pdf.

Mishkin F.S. (2004). Can inflation targeting work in emerging market countries? In Festschrift in Honour of Guillermo Calvo, International Monetary [Online] Available: http://www.imf.org/external/np/res/seminars/2004/calvo/pdf/mishki.pdf.

Mishkin, F.S. \& Savastano, M. A. (2002). Monetary policy strategies for emerging market countries: lessons from Latin America. International Monetary Fund.

Mishkin, F.S \& Savastano, M.A. (2001). Monetary policy strategies for Latin America. Journal of Development Economics, 66, 415-444.

Mohanty, M.S \& Turner,P. (2006). Foreign exchange reserve accumulation in emerging markets: what are the domestic implications? BIS Quarterly Review. [Online] Available: http://www.bis.org/publ/qtrpdf/r_qt0609f.pdf.

Mohanty,M.S. \& Klau,M. (2004). Monetary policy rules in emerging market economies: issues and evidence. Bank of International Settlements. BIS working papers no. 149. [Online] Available: http://papers.ssrn.com/sol3/papers.cfm?abstract_id=901388.

Neely,C. J. (2000). Are changes in foreign exchange reserves well correlated with official intervention? Federal Reserve Bank of St. Louis. [Online] Available: http://research.stlouisfed.org/publications/review/00/09/0009cn.pdf. 
Nogueira Junior, R. P. (2007). Inflation targeting and the role of exchange rate pass-through. University of Kent. [Online] Available: ftp://ftp.ukc.ac.uk/pub/ejr/RePEc/ukc/ukcedp/0602.pdf.

Osawa, N. (2006). Monetary policy responses to the exchange rate: empirical evidence from three East Asian inflation-targeting countries. Bank of Japan working paper series no. 06-E-14. [Online] Available: http://www.boj.or.jp/en/type/ronbun/ron/wps/data/wp06e14.pdf.

Ramaswamy,R \& Sloek,T. (1997). The real effects of monetary policy in the European Union: what are the differences? IMF working paper WP/97/160. [Online] Available: http://papers.ssrn.com/sol3/papers.cfm?abstract_id=882744.

Reyes,J.A. (2004). Exchange rate pass-through effect and inflation targeting in emerging economies: what is the relationship? University of

http://comp.uark.edu/ reyes/Files/Research/PassthroughIT.pdf.

Arkansas. [Online]

Available:

Sarno, L \& Taylor, M. P. (2001). Official intervention in the foreign exchange market: is it effective and, if so, how does it work? Journal of Economic Literature, XXXIX, 839-868.

Schmidt-Hebbel, Klaus \& Werner, A. (2002). Inflation targeting in Brazil, Chile and Mexico: performance, credibility and the exchange rate. Economia, 2(2), 31-89.

Senay, O. (2001). The role of the exchange rate in monetary policy rules. University of York. [Online] Available:http://www.econ.metu.edu.tr/people/osenay/senaympr.pdf.

Taylor, J. B. (1999). The robustness and efficiency of monetary policy rules as guidelines for interest rate setting by the European Central Bank. Journal of Monetary Economics, 43, 655-679.

Taylor, J. B. (2001). The role of the exchange rate in monetary policy rules. American Economic Review, 91(2), 263-267.

Taylor, J. B. (2000). Low inflation, pass-through, and the pricing power of firms. European Economic Review, 44(7), 1389-1408.

\section{Notes}

Note 1. The data for pre-crisis period used in SVAR analysis is mentioned in Table I(4), Appendix I. The data for the pre-crisis period used in GMM analysis spans from 1990M5 to 1997M6.

Note 2. Korea officially adopted the headline CPI inflation targeting regime in April 1998 and later switched to core CPI in January 2000 (Osawa, 2006).

Note3. Transforming the series in differenced may ignore the long-run relationships of variables. However, the main focus of this paper is to investigate the responses of short-run interest rate policy to inflation, output and exchange rate.

Note4. Impulse dummy is considered in case significant impulse or break of series is detected/ suggested by the unit-root with structural break test.

Note5. In this study, I only consider the stationary variables, however as discussed in Breitung et. al (2004), the SVAR modeling can use the variables fitted to the levels ignoring the unit-root and cointegration resctrictions to avoid imposing too many restrictions.

Note 6. The conditions hold based on the bilateral nominal exchange rate of USD against domestic currency.

Note 7. The instrument variables include the constant and one to four lags on all the endogenous variables.

Note 8. In Philippines, the nominal bilateral exchange rate and the nominal effective exchange rate of lag one and two are included as instrument variables in addition to the instrument variables as in Korea and Thailand. 


\section{Appendix}

Table 1. Monetary Policy Framework

\begin{tabular}{|c|c|c|}
\hline No & Countries & Monetary Policy Framework \\
\hline 1 & Korea & $\begin{array}{l}\text { Three main periods: } \\
\text { Monetary targeting } \\
\text { Since 1957, M1 was pre-announced quarterly or yearly as a macroeconomics policy } \\
\text { In 1979, monetary target changed to a M2 growth rate till mid } 1990 \mathrm{~s} \\
\text { After crisis } 1997-98 \text {, accepted IMF rescue financing plan, used M3 as reference value of monetary base, at the same } \\
\text { time, adopted inflation targeting (two pillar system) } \\
\text { In 2001, monitored M3 growth and the monitoring ended in } 2003 \text { with a pure inflation targeting } \\
\text { Interest rate as an operational target } \\
\text { After 1997-98, the interest rate was accepted as an operational target. } \\
\text { Since } 1999 \text {, Monetary Policy Committee (MPC) announced the target call rate for interest rate. } \\
\text { Inflation targeting } \\
\text { Since 2000, core CPI inflation rate has been chosen as the benchmark inflation indicator. } \\
\text { The target rate is determined annually with the range of }+/-1 \% \text {. } \\
\text { Official exchange rate regimes: } \\
\text { March 1980-October 1997----Managed floating } \\
\text { November 1997-present----Independently floating }\end{array}$ \\
\hline 2 & Philippines & $\begin{array}{l}\text { Two periods: } \\
\text { Monetary targeting } \\
\text { In the past, monetary policy framework based on base or reserve money programming. } \\
\text { Inflation targeting ( } 2002 \text { onwards) } \\
\text { Inflation targeting policy adopted officially in January } 2000 \text { and the implementation started in January } 2002 \text {. } \\
\text { CPI or headline inflation is used as its monetary policy target and overnight repurchase rate and reverse repurchase } \\
\text { rate are used as the main instrument of monetary policy. } \\
\text { Official exchange rate regimes: } \\
\text { January 1988-present----Independently floating }\end{array}$ \\
\hline 3 & Thailand & $\begin{array}{l}\text { Three main periods: } \\
\text { Pegged exchange rate regime ( } 2^{\text {nd }} \text { World War-June 1997) } \\
\quad \text { The value of Baht was pegged to a major currency/ gold or to a basket of currencies } \\
\text { Monetary targeting regime (July 1997-May 2000) } \\
\text { Beginning the periods of floating exchange rate. } \\
\text { Received assistance from IMF, targeted at domestic money supply. } \\
\text { Set daily and quarterly monetary base targets. } \\
\text { Inflation targeting regime (May 2000-present) } \\
\text { Inflation targeting is more effective as the relationship between money supply and output growth was becoming less } \\
\text { stable after financial crisis. } \\
\text { Official exchange rate regimes: } \\
\text { January 1970-June 1997-----fixed } \\
\text { July 1997-present----Independently floating }\end{array}$ \\
\hline
\end{tabular}

Sources: Hernandez \& Montiel (2001), IMF \& BIS

Table 2. Volatility of Exchange Rate, Foreign Exchange Reserves and Interest Rate

\begin{tabular}{|c|c|c|c|c|c|c|}
\hline & \multicolumn{2}{|c|}{ Korea } & \multicolumn{2}{|c|}{ Philippines } & \multicolumn{2}{|c|}{ Thailand } \\
\hline & Pre-crisis & Post-crisis & Pre-crisis & Post-crisis & Pre-crisis & $\begin{array}{c}\text { Post-crisi } \\
\text { s }\end{array}$ \\
\hline Exchange rate & 0.70 & 2.18 & 2.21 & 2.28 & 0.46 & 1.95 \\
\hline Foreign exchange reserves & 3.59 & 1.88 & 12.42 & 3.43 & 2.65 & 2.22 \\
\hline Interest rate & 1.07 & 0.60 & 1.46 & 0.89 & 1.39 & 0.75 \\
\hline
\end{tabular}

Notes: Crisis periods are defined as November 1997 to April 1998 for Korea, and July 1997 to April 1998 for Thailand and Philippines. Pre-crisis and post-crisis are defined as before and after the crisis period for each country

Source: Osawa (2006) 
Table 3(a). List of Series, Definitions and Data sources for SVAR

\begin{tabular}{|c|c|c|c|}
\hline No. & Variables & Data & Sources \\
\hline 1 & $\begin{array}{l}\text { Logarithms of Nominal exchange rate } \\
\text { (EX) } \\
\text { Korea } \\
\text { Philippines } \\
\text { Thailand }\end{array}$ & $\begin{array}{l}\text { Logarithms of Bilateral exchange rate of } \\
\text { national currency per US Dollar. }\end{array}$ & $\begin{array}{l}\text { International Financial } \\
\text { Statistics (IFS), IMF }\end{array}$ \\
\hline 3 & $\begin{array}{l}\text { Logarithms of Consumer Price Index } \\
\text { (CPI) } \\
\text { Korea } \\
\text { Philippines } \\
\text { Thailand }\end{array}$ & Logarithms of Consumer Price Index & $\begin{array}{l}\text { International Financial } \\
\text { Statistics (IFS), IMF }\end{array}$ \\
\hline 4 & $\begin{array}{l}\text { Logarithms of money demand (M) } \\
\text { Korea } \\
\text { Philippines } \\
\text { Thailand }\end{array}$ & Logarithms of M1 & $\begin{array}{l}\text { International Financial } \\
\text { Statistics (IFS), IMF } \\
\text { and OECD dataset }\end{array}$ \\
\hline 5 & $\begin{array}{l}\text { Output (IP) } \\
\text { Korea } \\
\text { Philippines } \\
\text { Thailand }\end{array}$ & $\begin{array}{l}\text { Logarithms of industrial production index; } \\
\text { Thailand uses logarithms in GDP }\end{array}$ & $\begin{array}{l}\text { International Financial } \\
\text { Statistics (IFS), IMF } \\
\text { and BOT }\end{array}$ \\
\hline 6 & Federal Fund Rate (FFR) & Level of U.S Federal Fund Rate & $\begin{array}{l}\text { International Financial } \\
\text { Statistics (IFS), IMF }\end{array}$ \\
\hline
\end{tabular}

Table 3(b). List of Series, Definitions and Data sources for GMM

\begin{tabular}{|l|l|l|l|}
\hline \multicolumn{1}{|c|}{ No. } & \multicolumn{1}{|c|}{ Variables } & \multicolumn{1}{|c|}{ Definitions } & \multicolumn{1}{c|}{ Sources } \\
\hline 1 & Interest rate & Money market rate & $\begin{array}{l}\text { International Financial } \\
\text { Statistics (IFS), IMF }\end{array}$ \\
\hline 2 & Inflation (annual) & {$\left[\left(c p i_{t}-c p i_{t-12}\right) / c p i_{t-12}\right]$} & $\begin{array}{l}\text { International Financial } \\
\text { Statistics (IFS), IMF }\end{array}$ \\
\hline 3 & Output gap & $\begin{array}{l}\text { Log differenced of industrial production index } \\
\text { from its HP filter trend series }\end{array}$ & $\begin{array}{l}\text { International Financial } \\
\text { Statistics (IFS), IMF }\end{array}$ \\
\hline 4 & $\begin{array}{l}\text { Growth in exchange } \\
\text { rate }\end{array}$ & $\begin{array}{l}\text { Log differenced of exchange rate from its first } \\
\text { lagged term }\end{array}$ & $\begin{array}{l}\text { International Financial } \\
\text { Statistics (IFS), IMF }\end{array}$ \\
\hline
\end{tabular}


Table 4. Unit-root Test for Stationarity

\begin{tabular}{|c|c|c|c|c|c|}
\hline \multirow[t]{2}{*}{ Countries } & \multirow[t]{2}{*}{ Variables } & \multicolumn{2}{|c|}{ Period I } & \multicolumn{2}{|c|}{ Period II } \\
\hline & & ADF & SP & ADF & $\mathbf{S P}$ \\
\hline \multirow[t]{10}{*}{ Korea } & cpi & $-3.3311 *$ & -1.4531 & -2.8168 & $-3.3256 * * *$ \\
\hline & dcpi & $-6.2544 * * *$ & $-6.3056 * * *$ & $-7.6000 * * *$ & $-7.1676^{* * *}$ \\
\hline & ex & -1.4323 & -1.0312 & -2.7569 & -1.4241 \\
\hline & $\operatorname{dex}$ & $-3.7609 * * *$ & $-5.8706 * * *$ & $-4.5170 * * *$ & $-7.5151 * * *$ \\
\hline & ip & $-5.1666^{* * *}$ & $-5.8275 * * *$ & $-5.6817 * * *$ & $-7.6071 * * *$ \\
\hline & $\operatorname{dip}$ & $-10.0004 * * *$ & $-9.9964 * * *$ & $-8.8114 * * *$ & $-13.0901 * * *$ \\
\hline & $\mathrm{i}$ & $-3.3909^{*}$ & $-3.0344 * *$ & -1.2414 & -1.4410 \\
\hline & $\mathrm{di}$ & $-6.0716 * * *$ & $-8.9032 * * *$ & $-3.7599 * * *$ & $-5.4840 * * *$ \\
\hline & $\mathrm{m}$ & -1.5036 & -1.0335 & -0.3119 & -1.6578 \\
\hline & $\mathrm{dm}$ & $-5.9502 * * *$ & $-6.9428 * * *$ & $-2.7503^{*}$ & $-3.7149 * * *$ \\
\hline \multirow[t]{10}{*}{ Philippines } & cpi & -2.6873 & -1.5936 & -1.5210 & -1.3460 \\
\hline & dcpi & $-4.5714 * * *$ & $-4.8487 * * *$ & $-4.9629 * * *$ & $-6.5703 * * *$ \\
\hline & ex & $-3.3279 *$ & -1.7709 & -1.6341 & -1.3213 \\
\hline & $\operatorname{dex}$ & $-5.0201 * * *$ & $-9.7624 * * *$ & $-3.8535 * * *$ & $-9.8971 * * *$ \\
\hline & ip & -2.8921 & $-5.7595 * * *$ & $-3.1840^{*}$ & $-4.5800 * * *$ \\
\hline & dip & $-8.5704 * * *$ & $-10.9489 * * *$ & $-6.3263 * * *$ & $-10.5865^{* * *}$ \\
\hline & $\mathrm{i}$ & $-4.6807 * * *$ & $-6.8402 * * *$ & -2.2392 & -2.0671 \\
\hline & $\mathrm{di}$ & $-8.5805 * * *$ & $-11.5418 * * *$ & $-5.3103 * * *$ & $-5.9204 * * *$ \\
\hline & $\mathrm{m}$ & $-3.9118 * *$ & $4.6786^{* * *}$ & -1.5513 & -2.3199 \\
\hline & $\mathrm{dm}$ & $-7.8396^{* * *}$ & $-9.8818 * * *$ & $-6.7730 * * *$ & $-3.1082 * *$ \\
\hline \multirow[t]{10}{*}{ Thailand } & cpi & -1.9359 & -2.2179 & -1.4798 & -1.5117 \\
\hline & dcpi & $-5.8941 * * *$ & $-6.5645 * * *$ & $-4.5008 * * *$ & $-6.8421 * * *$ \\
\hline & ex & -2.1144 & -2.3002 & $-3.2142 *$ & -1.5767 \\
\hline & dex & $-4.5419 * * *$ & $-7.1378 * * *$ & $-4.0105 * * *$ & $-8.2006^{* * *}$ \\
\hline & ip & $-4.2741 * * *$ & $-5.2168 * * *$ & $-3.1506^{*}$ & $-8.6148 * * *$ \\
\hline & dip & $-6.6303 * * *$ & $-14.2456^{* * * *}$ & $-8.5779 * * *$ & $-12.3351 * * *$ \\
\hline & $\mathrm{i}$ & -2.5067 & $-3.2967 * *$ & -3.1270 & -2.4393 \\
\hline & di & $-6.7255^{* * *}$ & $-8.4554 * * *$ & $-4.6891 * * *$ & $-5.0977 * * *$ \\
\hline & $\mathrm{m}$ & $-3.6285^{* *}$ & -2.1545 & -0.9260 & -1.8921 \\
\hline & $\mathrm{dm}$ & $-5.0753 * * *$ & $-4.7797 * * *$ & $-4.7022 * * *$ & $-3.4082 * *$ \\
\hline \multirow[t]{5}{*}{ U.S } & ffr & -1.9534 & -0.8631 & -1.6172 & -1.0438 \\
\hline & dffr & -2.4857 & $-5.7729 * * *$ & -2.2359 & -2.7507 \\
\hline & ddffr & $-6.8503 * * *$ & $-14.1540 * * *$ & $-7.2317 * * *$ & $8.6900 * * *$ \\
\hline & oil & $-3.6711 * *$ & $-3.2326 * *$ & -2.1468 & -1.9390 \\
\hline & doil & $-5.3089 * * *$ & $-6.0117 * * *$ & $-5.9282 * * *$ & $-8.8306^{* * *}$ \\
\hline
\end{tabular}

Notes: ${ }^{* * *}$ denotes the significant statistic at $1 \%$ level

** denotes the significant statistic at 5\% level

$*$ denotes the significant statistic at $10 \%$ level

"d" denotes the first differenced on the original series

All the variables are in logarithm form except " ffr and i

ADF denotes Augmented Dicky FullerTest and SP denotes Schmidt PhillipsTest; the specifications for ADF consist of 2 lags, constant and trend for all level of variables and constant and 2 lags for differenced variables. 
Table 5. Model Specifications and Diagnostic Test for SVAR

\begin{tabular}{|c|c|c|c|c|c|c|}
\hline \multirow[t]{2}{*}{ Test } & \multicolumn{2}{|c|}{ Korea } & \multicolumn{2}{|c|}{ Philippines } & \multicolumn{2}{|c|}{ Thailand } \\
\hline & Period I & Period II & Period I & Period II & Period I & Period II \\
\hline$\frac{\text { Test for }}{\text { Autocorrelation }}$ & & & & & & \\
\hline Portmanteau Test & $\begin{array}{l}671.1281 \\
(0.6198)\end{array}$ & $\begin{array}{l}691.4877 \\
(0.6447)\end{array}$ & $\begin{array}{l}855.0112 \\
(0.2663)\end{array}$ & $\begin{array}{l}726.9652 \\
(0.4516)\end{array}$ & $\begin{array}{l}845.7450 \\
(0.4765)\end{array}$ & $\begin{array}{l}687.5960 \\
(0.2882)\end{array}$ \\
\hline $\begin{array}{l}\text { Test for } \\
\text { Non-normality }\end{array}$ & & & & & & \\
\hline Doornik \& Hansen: & & & & & & \\
\hline Joint t-stat & $\begin{array}{l}15.8140 \\
(0.3249)\end{array}$ & $\begin{array}{l}17.0212 \\
(0.2550)\end{array}$ & $\begin{array}{l}28.2335 \\
(0.0132)\end{array}$ & $\begin{array}{l}50.9652 \\
(0.0000)\end{array}$ & $\begin{array}{l}19.9 / 06 \\
(0.1311)\end{array}$ & $\begin{array}{l}9.2254 \\
(0.8163)\end{array}$ \\
\hline Skewness only & $\begin{array}{c}8.7576 \\
(0.2705)\end{array}$ & $\begin{array}{l}12.0228 \\
(0.0998)\end{array}$ & $\begin{array}{l}14.7040 \\
(0.0400)\end{array}$ & $\begin{array}{l}14.9014 \\
(0.0377)\end{array}$ & $\begin{array}{c}9.6279 \\
(0.2107)\end{array}$ & $\begin{array}{c}7.1064 \\
(0.4179)\end{array}$ \\
\hline Kurtosis only & $\begin{array}{r}7.0565 \\
(0.4230) \\
\end{array}$ & $\begin{array}{r}4.9984 \\
(0.6602) \\
\end{array}$ & $\begin{array}{l}13.5295 \\
(0.0602) \\
\end{array}$ & $\begin{array}{l}36.0639 \\
(0.0000) \\
\end{array}$ & $\begin{array}{l}10.3427 \\
(0.1700) \\
\end{array}$ & $\begin{array}{c}2.1190 \\
(0.9530) \\
\end{array}$ \\
\hline $\begin{array}{l}\text { Test for Conditional } \\
\text { Heteroskedasticity }\end{array}$ & & & & & & \\
\hline $\begin{array}{l}\text { ARCH-LM Test } \\
\text { u1 }\end{array}$ & $\begin{array}{l}14.6828 \\
(0.5480)\end{array}$ & $\begin{array}{l}10.4000 \\
(0.8449)\end{array}$ & $\begin{array}{c}6.0016 \\
(0.9881)\end{array}$ & $\begin{array}{l}14.0076 \\
(0.5982)\end{array}$ & $\begin{array}{c}9.8723 \\
(0.8732)\end{array}$ & $\begin{array}{c}14.951 \\
(0.5279)\end{array}$ \\
\hline u2 & $\begin{array}{c}8.8440 \\
(0.9197)\end{array}$ & $\begin{array}{l}19.0078 \\
(0.2683)\end{array}$ & $\begin{array}{c}8.9711 \\
(0.9146)\end{array}$ & $\begin{array}{c}8.6384 \\
(0.9276)\end{array}$ & $\begin{array}{c}9.4439 \\
(0.8940)\end{array}$ & $\begin{array}{l}16.3431 \\
(0.4293)\end{array}$ \\
\hline u3 & $\begin{array}{l}12.7476 \\
(0.6911)\end{array}$ & $\begin{array}{l}24.4074 \\
(0.0810)\end{array}$ & $\begin{array}{l}15.5181 \\
(0.4871)\end{array}$ & $\begin{array}{l}10.6626 \\
(0.8298)\end{array}$ & $\begin{array}{l}13.6724 \\
(0.6231)\end{array}$ & $\begin{array}{l}12.2567 \\
(0.7259)\end{array}$ \\
\hline u4 & $\begin{array}{l}17.7327 \\
(0.3398)\end{array}$ & $\begin{array}{c}7.4283 \\
(0.9641)\end{array}$ & $\begin{array}{l}20.5765 \\
(0.1954)\end{array}$ & $\begin{array}{c}8.5830 \\
(0.9296)\end{array}$ & $\begin{array}{l}10.3828 \\
(0.8459)\end{array}$ & $\begin{array}{l}10.2767 \\
(0.8518)\end{array}$ \\
\hline u5 & $\begin{array}{l}15.9075 \\
(0.4594)\end{array}$ & $\begin{array}{c}7.8549 \\
(0.9531)\end{array}$ & $\begin{array}{c}8.2195 \\
(0.9421)\end{array}$ & $\begin{array}{c}9.4193 \\
(0.8951)\end{array}$ & $\begin{array}{c}5.9364 \\
(0.9888)\end{array}$ & $\begin{array}{l}15.1230 \\
(0.5156)\end{array}$ \\
\hline u6 & $\begin{array}{l}14.6469 \\
(0.5506)\end{array}$ & $\begin{array}{c}9.6358 \\
(0.8849)\end{array}$ & $\begin{array}{l}10.8995 \\
(0.8156)\end{array}$ & $\begin{array}{l}11.5924 \\
(0.7715)\end{array}$ & $\begin{array}{l}15.9281 \\
(0.4580)\end{array}$ & $\begin{array}{c}9.8401 \\
(0.8748)\end{array}$ \\
\hline u7 & $\begin{array}{r}16.7558 \\
(0.4016) \\
\end{array}$ & $\begin{array}{c}7.6755 \\
(0.9579) \\
\end{array}$ & $\begin{array}{l}25.3313 \\
(0.6242) \\
\end{array}$ & $\begin{array}{l}15.3974 \\
(0.4958) \\
\end{array}$ & $\begin{array}{r}10.8397 \\
(0.8793) \\
\end{array}$ & $\begin{array}{l}13.5417 \\
(0.6328) \\
\end{array}$ \\
\hline Specifications & $\mathrm{C}, \mathrm{S}, \mathrm{T}, 5$ lags & $\begin{array}{l}\mathrm{C}, \mathrm{S}, \mathrm{T}, \\
4 \text { lags, } \\
\text { imp01m10, } \\
\text { Imp05m11 }\end{array}$ & $\begin{array}{l}\text { S,C,T, } 3 \text { lags, } \\
\text { Imp90m8 }\end{array}$ & $\begin{array}{l}\text { C, S, } 3 \text { lags, } \\
\text { imp02m11, } \\
\text { Imp04m6 }\end{array}$ & $\begin{array}{l}\mathrm{C,S}, \mathrm{T}, \\
2 \text { lags, imp90m8 }\end{array}$ & C,S, 5 lags \\
\hline Samples & 1991M1-1997M4 & 2000M1-2007M5 & 1989M6-1997M6 & 2001M6-2007M2 & 1990M1-1997M6 & 2000M5-2006M12 \\
\hline
\end{tabular}

Notes:

The upper numbers are the t-statistics and the parentheses values are the p-values. Most of the numbers are not significant at 5\% level and cannot reject the null hypothesis of no autocorrelation, normality and no conditional heteroskedasticity with the exception of Philippines due to short series.

$\mathrm{C}$ denotes the constant, $\mathrm{S}$ is seasonal dummies and $\mathrm{T}$ is trend. 
Table 6. Estimated coefficients for SVAR

\begin{tabular}{|c|c|c|c|c|c|c|}
\hline & \multicolumn{3}{|c|}{ Period I } & \multicolumn{3}{|c|}{ Period II } \\
\hline & Korea & Philippines & Thailand & Korea & Philippines & Thailand \\
\hline G13 & $\begin{array}{l}-64.0135 \\
(71.3225)\end{array}$ & $\begin{array}{l}-46.8214 \\
(99.9663)\end{array}$ & $\begin{array}{c}-12.3383 \\
(74.7000)\end{array}$ & $\begin{array}{c}\mathbf{0 . 2 1 2 6} \\
(4.7981)\end{array}$ & $\begin{array}{c}-38.0754 \\
(14.1206)\end{array}$ & $\begin{array}{c}-55.6241 \\
(76.5138)\end{array}$ \\
\hline G14 & $\begin{array}{c}2.0925 \\
(5.6228)\end{array}$ & $\begin{array}{c}-25.5912 \\
(13.0309)\end{array}$ & $\begin{array}{c}20.8797 \\
(10.3171)\end{array}$ & $\begin{array}{c}-0.6398 \\
(0.3479)\end{array}$ & $\begin{array}{l}-0.0754 \\
(0.9993)\end{array}$ & $\begin{array}{c}-7.5323 \\
(12.6054)\end{array}$ \\
\hline G15 & $\begin{array}{c}5.9585 \\
(2.7856)\end{array}$ & $\begin{array}{l}-6.0239 \\
(7.5734)\end{array}$ & $\begin{array}{l}-9.9200 \\
(5.8617)\end{array}$ & $\begin{array}{c}-0.0474 \\
(0.1257)\end{array}$ & $\begin{array}{c}0.6095 \\
(0.7694)\end{array}$ & $\begin{array}{c}-2.7306 \\
(3.1083)\end{array}$ \\
\hline G17 & $\begin{array}{l}- \\
-\end{array}$ & $\begin{array}{c}-11.6141 \\
(111.4808)\end{array}$ & $\begin{array}{c}-88.4873 \\
(250.5432)\end{array}$ & $\begin{array}{l}-0.7507 \\
(2.5363)\end{array}$ & $\begin{array}{c}-4.8488 \\
(13.8029)\end{array}$ & $\begin{array}{l}-72.2476 \\
(99.5841)\end{array}$ \\
\hline G21 & $\begin{array}{c}0.0036 \\
(0.0006)\end{array}$ & $\begin{array}{c}0.0011 \\
(0.0006)\end{array}$ & $\begin{array}{c}0.0013 \\
(0.0013)\end{array}$ & $\begin{array}{c}0.0157 \\
(0.0127)\end{array}$ & $\begin{array}{c}-0.0004 \\
(0.0057)\end{array}$ & $\begin{array}{c}-0.1132 \\
(0.0453)\end{array}$ \\
\hline G23 & $\begin{array}{c}0.3964 \\
(0.3474)\end{array}$ & $\begin{array}{l}-0.8687 \\
(0.3682)\end{array}$ & $\begin{array}{l}-0.0110 \\
(0.7671)\end{array}$ & $\begin{array}{c}0.4068 \\
(0.3303)\end{array}$ & $\begin{array}{c}0.5259 \\
(0.6445)\end{array}$ & $\begin{array}{c}0.3906 \\
(0.8887)\end{array}$ \\
\hline G24 & $\begin{array}{c}0.0513 \\
(0.0287)\end{array}$ & $\begin{array}{c}0.0320 \\
(0.0456)\end{array}$ & $\begin{array}{c}0.0824- \\
(0.1128)\end{array}$ & $\begin{array}{c}-0.0624 \\
(0.0310)\end{array}$ & $\begin{array}{c}0.0618 \\
(0.0403)\end{array}$ & $\begin{array}{c}-0.3442 \\
(0.1299)\end{array}$ \\
\hline G34 & $\begin{array}{c}-0.0088 \\
(0.0093)\end{array}$ & $\begin{array}{c}0.0234 \\
(0.0120)\end{array}$ & $\begin{array}{c}-0.0054 \\
(0.6150)\end{array}$ & $\begin{array}{c}-0.0096 \\
(0.0093)\end{array}$ & $\begin{array}{c}0.0034 \\
(0.0079)\end{array}$ & $\begin{array}{l}-0.0050 \\
(0.0176)\end{array}$ \\
\hline G35 & $\begin{array}{c}-0.0117 \\
(0.0044)\end{array}$ & $\begin{array}{c}0.0125 \\
(0.0083)\end{array}$ & $\begin{array}{c}0.0058 \\
(0.0058)\end{array}$ & $\begin{array}{l}-0.0134 \\
(0.0033)\end{array}$ & $\begin{array}{l}-0.0056 \\
(0.0043)\end{array}$ & $\begin{array}{l}-0.0137 \\
(0.0055)\end{array}$ \\
\hline G45 & $\begin{array}{c}-0.0119 \\
(0.0564)\end{array}$ & $\begin{array}{c}0.0990 \\
(0.0700)\end{array}$ & $\begin{array}{c}0.0121 \\
(0.0409)\end{array}$ & $\begin{array}{c}0.0464 \\
(0.0389)\end{array}$ & $\begin{array}{c}0.1310 \\
(0.0620)\end{array}$ & $\begin{array}{c}0.0034 \\
(0.0361)\end{array}$ \\
\hline G65 & $\begin{array}{c}-0.0044 \\
(0.2504)\end{array}$ & $\begin{array}{l}-0.3686 \\
(0.2068)\end{array}$ & $\begin{array}{l}-0.4211 \\
(0.2355)\end{array}$ & $\begin{array}{l}-0.2884 \\
(0.1985)\end{array}$ & $\begin{array}{l}-0.0027 \\
(0.2047)\end{array}$ & $\begin{array}{l}-0.1813 \\
(0.1912)\end{array}$ \\
\hline G71 & $\begin{array}{c}-0.0013 \\
(0.0008)\end{array}$ & $\begin{array}{c}0.0011 \\
(0.0019)\end{array}$ & $\begin{array}{c}0.0013 \\
(0.0011)\end{array}$ & $\begin{array}{c}0.0488 \\
(0.1646)\end{array}$ & $\begin{array}{c}0.0229 \\
(0.0229)\end{array}$ & $\begin{array}{c}1.0929 \\
(2.2988)\end{array}$ \\
\hline G72 & $\begin{array}{l}-0.3139 \\
(0.1348)\end{array}$ & $\begin{array}{c}-0.2184 \\
(0.1051)\end{array}$ & $\begin{array}{c}0.0080 \\
(0.0194)\end{array}$ & $\begin{array}{c}0.2973 \\
(0.3074)\end{array}$ & $\begin{array}{c}-0.0080 \\
(0.1109)\end{array}$ & $\begin{array}{c}5.4647 \\
(11.5603)\end{array}$ \\
\hline G73 & $\begin{array}{c}0.3374 \\
(0.4191)\end{array}$ & $\begin{array}{l}-0.2097 \\
(0.3978)\end{array}$ & $\begin{array}{c}0.1214 \\
(0.1382)\end{array}$ & $\begin{array}{c}1.3063 \\
(0.9938)\end{array}$ & $\begin{array}{l}-0.9679 \\
(1.0487)\end{array}$ & $\begin{array}{c}-6.0908 \\
(15.2043)\end{array}$ \\
\hline G74 & $\begin{array}{l}-0.0581 \\
(0.0333)\end{array}$ & $\begin{array}{c}0.0218 \\
(0.0653)\end{array}$ & $\begin{array}{c}0.0443 \\
(0.0307)\end{array}$ & $\begin{array}{c}0.0057 \\
(0.1323)\end{array}$ & $\begin{array}{c}-0.0286 \\
(0.0388)\end{array}$ & $\begin{array}{c}-0.2246 \\
(1.1748)\end{array}$ \\
\hline $\begin{array}{l}\text { G75 } \\
\text { G76 }\end{array}$ & $\begin{array}{c}-0.0338 \\
(0.0167) \\
0.0048 \\
(0.0073)\end{array}$ & $\begin{array}{c}-0.0125 \\
(0.0331) \\
0.0333 \\
(0.0149)\end{array}$ & $\begin{array}{c}0.0106 \\
(0.0115) \\
-0.0074 \\
(0.0034)\end{array}$ & $\begin{array}{c}0.0100 \\
(0.0325) \\
-0.0256 \\
(0.0161)\end{array}$ & $\begin{array}{c}-0.0320 \\
(0.227 \\
(0.0117)\end{array}$ & $\begin{array}{c}-1.2572 \\
(2.7098) \\
-0.3830 \\
(0.8119) \\
\end{array}$ \\
\hline 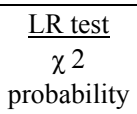 & $\begin{array}{l}9.1301 \\
0.1040\end{array}$ & $\begin{array}{l}3.6474 \\
0.4558\end{array}$ & $\begin{array}{l}1.3820 \\
0.8473\end{array}$ & $\begin{array}{l}2.4459 \\
0.6544\end{array}$ & $\begin{array}{l}4.3851 \\
0.3564\end{array}$ & $\begin{array}{l}1.5489 \\
0.8179\end{array}$ \\
\hline
\end{tabular}

Note: The number of over-identified variables is 4 in all cases but 5 in the case of Thailand in period I. The values in parentheses are the standard errors

Table 7. Impulse response functions: effects of shocks on monetary policy

\begin{tabular}{|c|c|c|c|c|c|c|c|}
\hline \multirow{2}{*}{ Shocks } & \multirow{2}{*}{ Periods } & \multicolumn{2}{|c|}{ Korea } & \multicolumn{2}{c|}{ Philippines } & \multicolumn{2}{c|}{ Thailand } \\
\cline { 2 - 8 } & & I & II & I & II & I & II \\
\hline \multirow{2}{*}{ CPI } & 1 & 0.0637 & 0.0077 & 0.1339 & 0.0687 & 0.0040 & 0.0260 \\
& 4 & 0.1015 & -0.0223 & 0.3135 & 0.1111 & 0.0358 & 0.0627 \\
& 8 & 0.1678 & -0.0327 & 0.1513 & 0.1498 & 0.0226 & 0.1330 \\
& 12 & 0.1659 & -0.0287 & 0.1725 & 0.1649 & 0.0308 & 0.1574 \\
& 16 & 0.1794 & -0.0234 & 0.3234 & 0.1712 & 0.0281 & 0.1608 \\
& 20 & 0.2039 & -0.0212 & 0.4814 & 0.1750 & 0.0280 & 0.1597 \\
\hline Output gap & 1 & 0.1677 & 0.0169 & 0.7828 & 0.0016 & -0.4633 & -0.0001 \\
& 4 & 0.0676 & 0.0185 & 0.9805 & 0.0207 & -0.3983 & -0.0217 \\
& 8 & 0.1820 & 0.0027 & 0.3632 & 0.0233 & -0.3727 & -0.0486 \\
& 12 & 0.1310 & -0.0066 & 0.4399 & 0.0265 & -0.3391 & -0.0583 \\
& 16 & 0.2214 & -0.0102 & 0.7381 & 0.0284 & -0.3225 & -0.0458 \\
& 20 & 0.3018 & -0.0099 & 0.5474 & 0.0288 & -0.3117 & -0.0515 \\
\hline Exchange rate & 1 & 0.0000 & 0.0221 & -0.6454 & 0.0371 & 0.3183 & 0.0613 \\
& 4 & 0.0855 & 0.0046 & -0.8560 & 0.8327 & 0.3581 & 0.0981 \\
& 8 & 0.3608 & -0.0053 & -1.0736 & 0.0940 & 0.3560 & 0.1164 \\
& 12 & 0.4519 & -0.0171 & -0.7889 & 0.0911 & 0.3503 & 0.1177 \\
& 16 & 0.5294 & -0.0141 & -1.0492 & 0.0889 & 0.3433 & 0.1225 \\
& 20 & 0.5972 & -0.0140 & -0.9833 & 0.0874 & 0.3404 & 0.1266 \\
\hline
\end{tabular}


Table 8. FEVD: Maximum effects of shocks on monetary policy

\begin{tabular}{|c|c|c|c|c|c|c|}
\hline Shocks & \multicolumn{2}{|c|}{ Korea } & \multicolumn{2}{c|}{ Philippines } & \multicolumn{2}{c|}{ Thailand } \\
\hline & I & II & I & II & I & II \\
\hline I & 0.94 & 0.86 & 0.94 & 0.85 & 0.84 & 0.04 \\
\hline M & 0.07 & 0.06 & 0.00 & 0.03 & 0.02 & 0.30 \\
\hline CPI & 0.02 & 0.03 & 0.01 & 0.11 & 0.00 & 0.17 \\
\hline IP & 0.06 & 0.11 & 0.07 & 0.03 & 0.06 & 0.08 \\
\hline OIL & 0.11 & 0.07 & 0.02 & 0.13 & 0.07 & 0.28 \\
\hline FFR & 0.08 & 0.04 & 0.01 & 0.01 & 0.07 & 0.06 \\
\hline EX & 0.03 & 0.02 & 0.04 & 0.04 & 0.03 & 0.43 \\
\hline
\end{tabular}

Notes: The maximum effects of shocks (in percentage) are obtained from FEVD generated by running the SVAR models.

Table 9(a). IRF:Effects of monetary policy on I, M and CPI

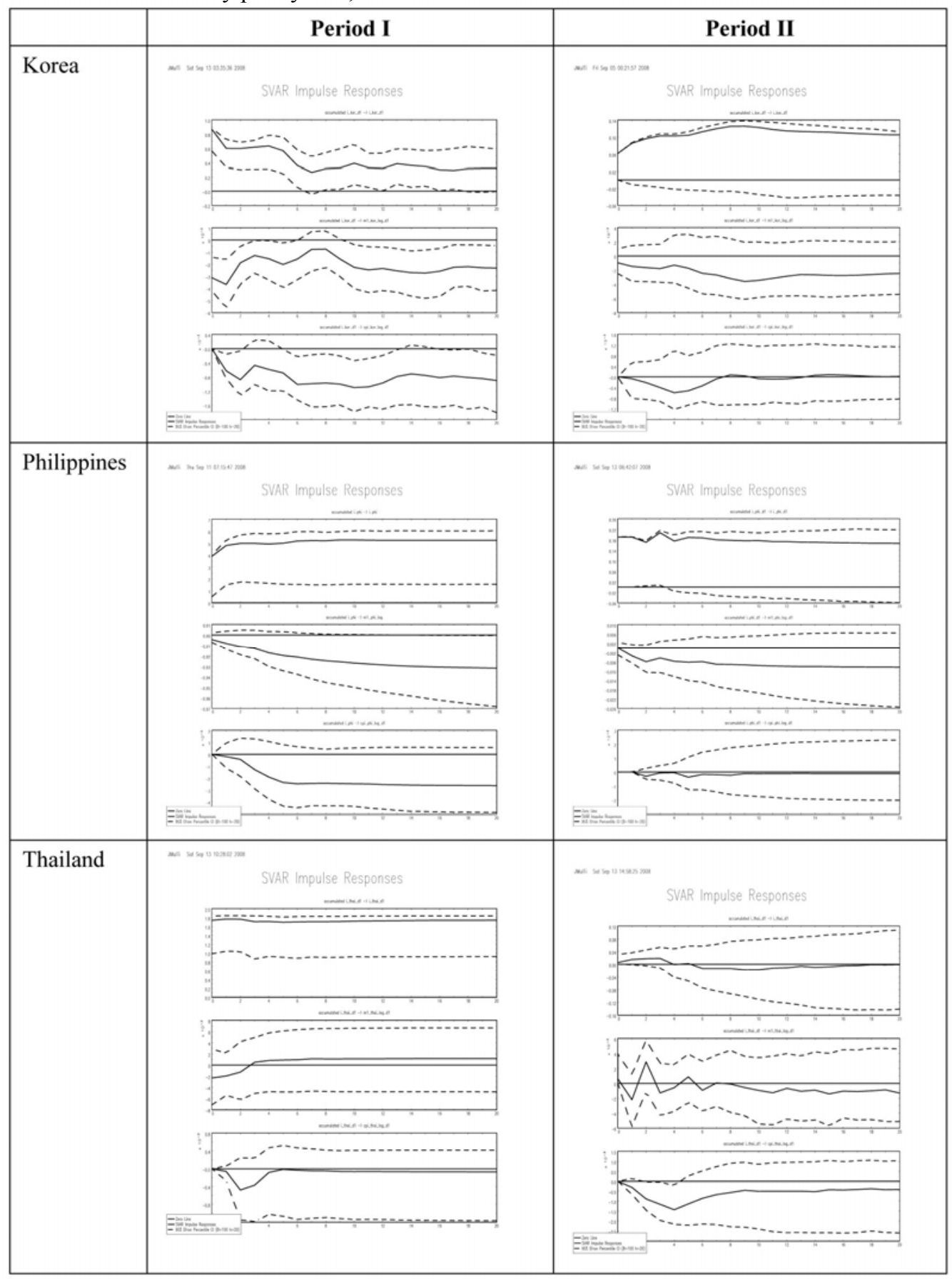

Notes: The figures show the effects of domestic monetary policy on I, m and CPI from the top to down ordering $\mathrm{M}$ denotes the monetary aggregate, I denotes the interest rate and EX is the exchange rate 
Table 9(b). IRF: effects of monetary policy shocks on IP and EX

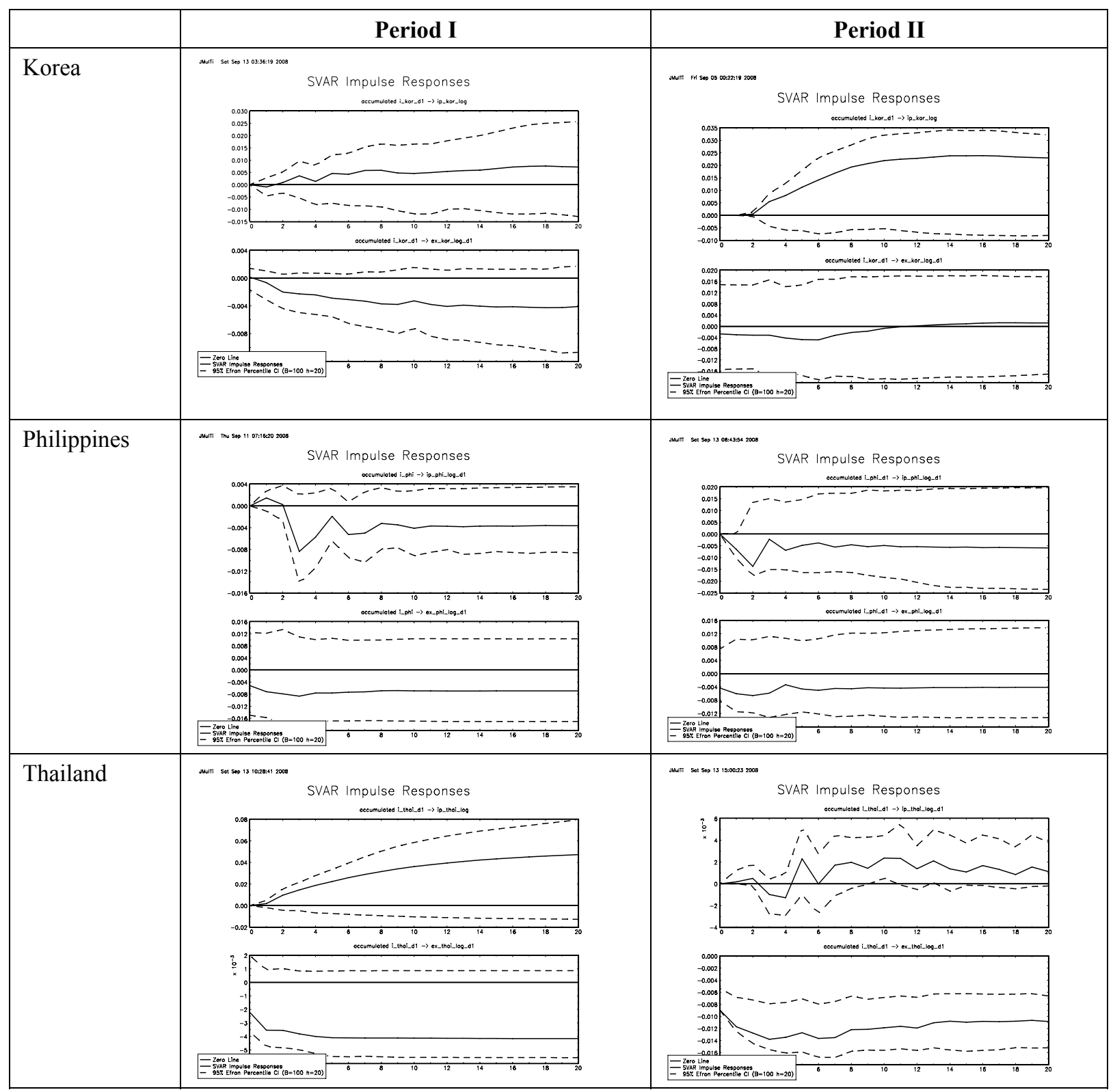

Notes:The figures show the effects of domestic monetary policy on GAP, and EX from the top to down ordering IP denotes the output, ex denotes nominal exchange rate 
Table 9(c). IRF: the responses of monetary policy to IP, CPI and EX shocks

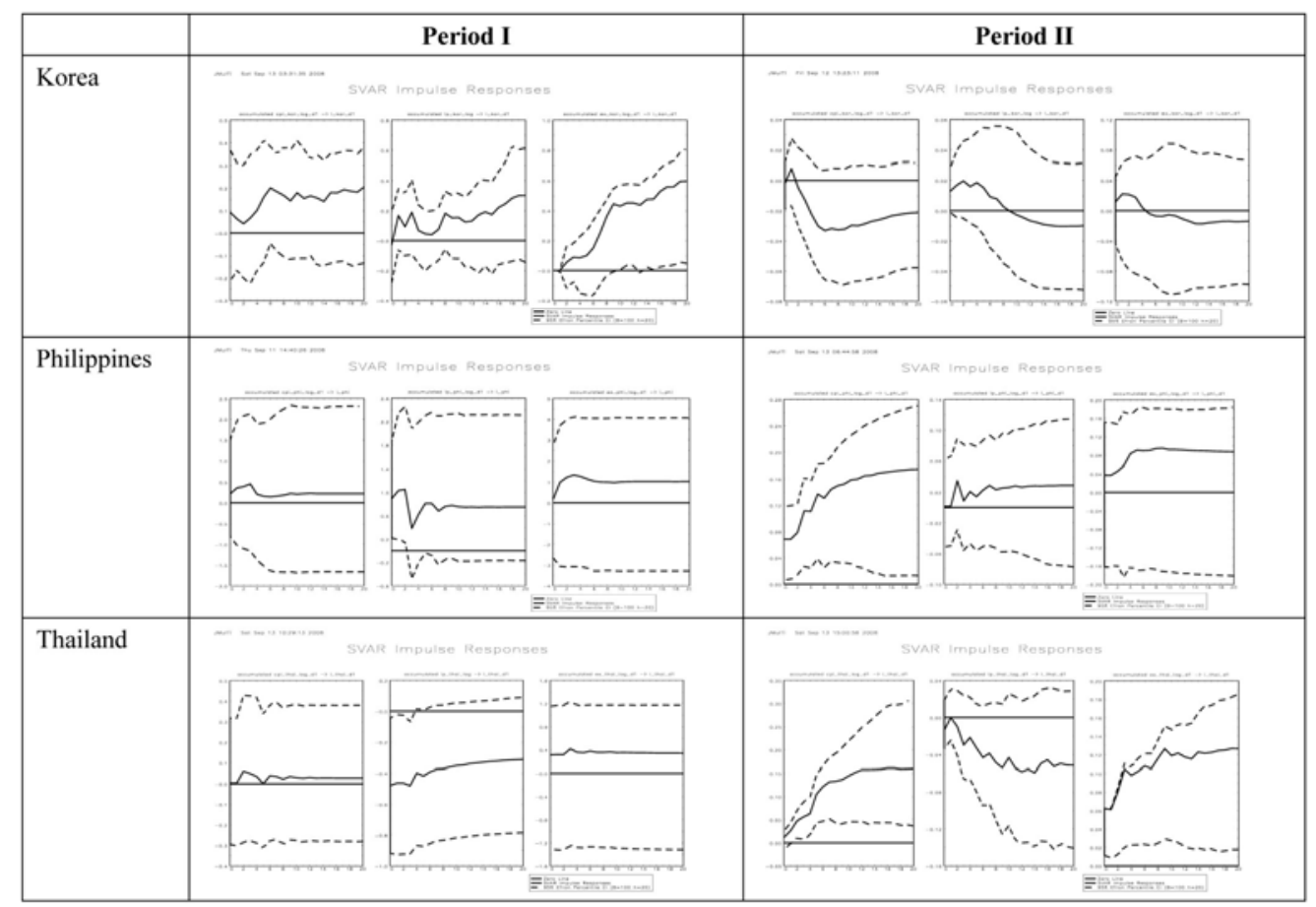

Notes:The figures show the impulses of CPI, IP and EX on monetary policy from the left to right ordering

Table 10. Interest rate and inflation rate (1990M5-2007M5)

\begin{tabular}{|c|c|}
\hline Countries & 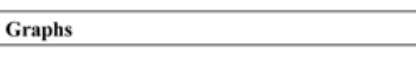 \\
\hline Korea & (25. \\
\hline Philippines & 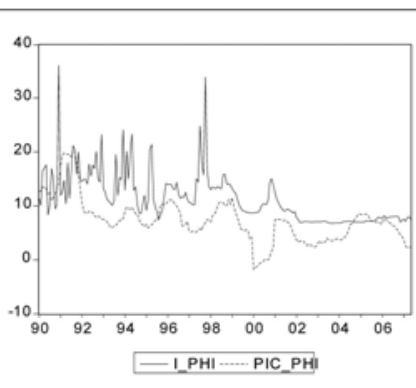 \\
\hline Thailand & 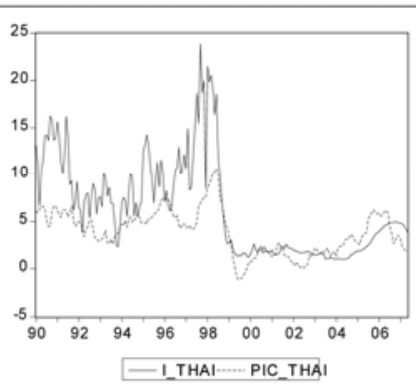 \\
\hline
\end{tabular}


Table 11. Estimated of simple rule with exchange rate terms

\begin{tabular}{|c|c|c|c|c|c|c|c|c|c|}
\hline Countries & Period & Pie & Gap & I(-1) & de & de(-1) & $\begin{array}{l}\text { Std. } \\
\text { error }\end{array}$ & J-stat & $\mathbf{R}^{2}$ \\
\hline Thailand & $\begin{array}{l}\text { I } \\
\text { II }\end{array}$ & $\begin{array}{l}0.2460 \\
0.0745^{* * *}\end{array}$ & $\begin{array}{l}0.0121 \\
-0.0001\end{array}$ & $\begin{array}{l}0.7924^{* * *} \\
0.9474^{* * * *}\end{array}$ & $\begin{array}{l}-1.5285^{* * *} \\
-0.0567^{* * * *}\end{array}$ & $\begin{array}{l}0.7733^{* *} \\
0.0188\end{array}$ & $\begin{array}{l}0.0206 \\
0.0021\end{array}$ & $\begin{array}{l}0.1021 \\
0.0864\end{array}$ & $\begin{array}{l}0.6233 \\
0.9721\end{array}$ \\
\hline
\end{tabular}

Notes:

*** denotes the significant level at $1 \%$ interval

** denotes the significant level at 5\% interval

* denotes the significant level at $10 \%$ interval

Chi-square $(12)=21.0$

Table 12. Simple rule without exchange rate terms

\begin{tabular}{|l|l|l|l|l|l|l|l|}
\hline \multicolumn{1}{|c|}{ Countries } & \multicolumn{1}{c|}{ Period } & \multicolumn{1}{c|}{ Pie } & \multicolumn{1}{c|}{ Gap } & \multicolumn{1}{c|}{ I(-1) } & \multicolumn{1}{c|}{ S.E } & \multicolumn{1}{c|}{ J-stat } & \multicolumn{1}{c|}{$\mathbf{R}^{2}$} \\
\hline Korea & Period I & $0.2045^{* * * *}$ & 0.0551 & $0.6641^{* * *}$ & 0.0121 & 0.0898 & 0.7148 \\
& Period II & $-0.0246^{* * *}$ & 0.0040 & $0.9962^{* * *}$ & 0.0009 & 0.0618 & 0.9781 \\
\hline Philippines & Period I & $0.1847^{* *}$ & 0.1111 & $0.3384^{* * *}$ & 0.0454 & 0.0935 & 0.0376 \\
& Period II & 0.0023 & $0.0231^{* * *}$ & $0.6040^{* * *}$ & 0.0026 & 0.1374 & 0.6000 \\
\hline Thailand & Period I & $0.4453^{* *}$ & -0.0450 & $0.6925^{* * *}$ & 0.0218 & 0.1338 & 0.5654 \\
& Period II & $0.0717^{* * *}$ & -0.0057 & $0.9520^{* * *}$ & 0.0017 & 0.1419 & 0.9813 \\
\hline
\end{tabular}

Notes: As mentioned below Table 11; Chi-square $(14)=23.7$ 